\title{
Assessment of foodborne pathogen presence in the peach supply chain and its potential risk to the end consumer
}

\author{
Stacey Duvenage, Lise Korsten* \\ Centre of Excellence in Food Security, Department of Plant and Soil Sciences, University of Pretoria, Lynnwood Road, Pretoria, 0001, South Africa
}

\section{A R T I C L E I N F O}

\section{Article history:}

Received 6 December 2016

Received in revised form

20 February 2017

Accepted 5 March 2017

Available online 16 March 2017

\section{Keywords:}

Stone fruit

Foodborne human pathogens

Risk assessment

Food safety

\begin{abstract}
A B S T R A C T
Peaches are popular, nutritious and widely consumed. Being a tree crop, it is considered a low risk fruit, with no direct water contact, and no previous foodborne disease outbreaks associated with its consumption. However, in 2014 the pioneer association between stone fruit and a foodborne illness was reported, linking Listeria monocytogenes to stone fruit. This highlights the need for better understanding of risk associated with contaminated fresh stone fruit, in order to implement adequate preventative measures. No information is available on the presence of foodborne pathogens on peaches in the supply chain. A case study approach was therefore followed to assess foodborne pathogen presence on the farm, focusing on the impact of irrigation water, facility sanitation and hygiene by collecting various fruit and environmental samples $(n=428)$. This study demonstrates the effectiveness of integrating basic microbial testing with safety management and risk assessment tools that can be collectively used to improve the food safety management system. No Salmonella Typhimurium was detected from samples, however, Escherichia coli 0157:H7, Listeria spp. and Staphylococcus aureus were detected on fruit and environmental samples. Despite the GlobalG.A.P. certification status of the farm, livestock frequented water sources which lead to E. coli 0157:H7 contamination. This conclusion was based on positive detection of foodborne pathogens from the water sources and subsequent removal of livestock which resulted in a definite decrease in pathogen detection. A number of E. coli 0157:H7 and S. aureus were detected during the second year of monitoring from environmental samples and it was observed that the personal hygiene and facility sanitation was not adequately enforced. Based on feedback given to the farmer, enforcement was improved and a definite decrease in foodborne pathogens was observed in the following sampling cycle. Areas of risk that were still identified following the fourth year of monitoring included the water source used for irrigation and poor sanitation in the production and processing facilities. Limited foodborne pathogen prevalence on peaches over the full study period as well as the extended export supply chain at controlled temperatures resulted in low-to-medium calculated consumer risk. The correct and meticulous implementation of integrated and holistic pre- and post-harvest food safety management systems is therefore essential to prevent produce contamination, reduce the consumer risk and therefore ensure overall product safety.
\end{abstract}

๑) 2017 Elsevier Ltd. All rights reserved.

\section{Introduction}

Escherichia coli 0157:H7, Listeria monocytogenes and Salmonella spp. are well described foodborne pathogens, having been associated with several disease outbreaks on fresh produce. Stone fruit are not traditionally considered a high-risk product due to production practices. However, in recent years' commodities

\footnotetext{
* Corresponding author. Private Bag X20, Hatfield, Pretoria, 0028, South Africa. E-mail addresses: stacey.duvenage@up.ac.za (S. Duvenage), lise.korsten@up.ac. za (L. Korsten).
}

previously not associated with foodborne disease outbreaks are becoming implicated, as was the case with the recent illnesses associated with $L$. monocytogenes on stone fruit (Jackson et al., 2015) and caramel apples [Centre for Disease Control and Prevention (CDC), 2015]. Due to extensive global distribution of fresh produce, outbreaks are not confined to the country of origin, as was the case in the June 2011 E. coli O104:H4 outbreak associated with contaminated sprouts, imported from Egypt, which affected 16 countries including 14 countries in the European Union (EU) as well as the United States of America (USA) and Canada [European Food Safety Authority (EFSA) (2011); World Health Organisation 


$\begin{array}{ll}\text { Abbreviations } \\ \text { CDC } & \text { Centre for Disease Control and Prevention } \\ \text { EFSA } & \text { European Food Safety Authority } \\ \text { EU } & \text { European Union } \\ \text { HSMS } & \text { Horticultural safety management system } \\ \text { RRR } & \text { Risk Ranger ranking } \\ \text { SA } & \text { South Africa } \\ \text { UK } & \text { United Kingdom } \\ \text { USA } & \text { United States of America } \\ \text { WHO } & \text { World Health Organisation }\end{array}$

(WHO), 2011]. Food safety assurance is therefore of global importance.

Peaches are packed and consumed raw without any decontamination, it is therefore essential to prevent contamination. Preharvest contamination can occur through contact with contaminated soil, irrigation water and improperly composted manure (Beuchat, 2002). The presence of animal farming in fields adjacent to cultivation areas (Gruszynski et al., 2014; Kilonzo et al., 2013) or cultivation in fields which are historically used for animal rearing (Tauxe et al., 1997) could lead to the spread of persistent foodborne pathogens. Postharvest contamination usually occurs through contact with contaminated harvesting equipment, handlers and contact surfaces (Beuchat, 2002; Warriner, Huber, Namvar, Fan, \& Dunfield, 2009).

Food safety standards and systems that target zero microbial contamination have been developed specifically for the food processing industries. However, the general philosophy is that zero tolerance is not realistic in a preharvest environment. Since microbiological analysis of food is time consuming, the International Commission on Microbiological Specification for Foods stated that "Good Agricultural Practices and acceptable hygienic farming practices are more important than microbiological testing of food samples before selling" (Food Science Australia, 2000). Good agricultural practices have been standardly adopted by the fresh produce industry and GlobalG.A.P. has become a global benchmark for exported produce. The use and implementation of effective food safety management systems should therefore provide additional food safety confidence.

The overall aim of this study was to determine 1) hazard presence, 2) on-farm risk areas and 3) end-consumers risk. The presence of E. coli 0157:H7, Listeria spp., Salmonella Typhimurium and Staphylococcus aureus in water, on pre- and post-harvest fruit and pre- and post-harvest contact surfaces was determined. The overall risk and risk areas as well as control were assessed using a selfdiagnostic tool (Kirezieva, Luning, Jacxsens, \& Uyttendaele, 2015; Kirezieva et al., 2013) and an easy-to-use semi-quantitative risk assessment tool (Ross \& Sumner, 2002).

\section{Experimental}

\subsection{Study site and sampling strategy}

An integrated commercial export farm managed according to industry guidelines and GlobalG.A.P. certified in the Limpopo Province, South Africa (SA) was selected as the site. This farm cultivated peaches, maize and citrus, in addition, the farm engaged in compost production, game and cattle livestock farming. Peaches (Prunus persica L.) were grown in uncovered fields, drip irrigated and conventional pesticide application with water sourced from on-farm collection dams filled with water from the Lephalala River. The farm's packhouse was located near the orchards (within $15 \mathrm{~km}$ ). Peaches were mainly exported to the UK and EU markets. Precipitation data was gathered from the South African Weather Services (2012).

A total of 428 samples were collected and analysed during four consecutive growing seasons (Table 1; Table 2). During seasons 1 and 4 the farm was visited once during the peak harvesting period, and during seasons 2 and 3 the farm was visited twice, once during the last spray period (one month prior to harvest) and once during the harvest period (Table 2$)$.

Water samples $(\mathrm{n}=95 ; 5 \times 1000 \mathrm{ml}$ per site) were collected using a telescopic water sampling arm (1.5 m) (Table 2). Water was collected from holding dams, river, pesticide fill point and at the packhouse. Prunus persica L. cv. Oom Sarel samples $(n=60)$ were collected from the orchard (preharvest) and from the packhouse (postharvest). In the orchard, fruit were collected from five trees from a single orchard block, at four points per tree and three fruit per point. Location of the trees were recorded and visited in subsequent seasons. Five fruit samples of three fruit were randomly collected before and after packing. Transport swabs with Amies medium (Lasec, Johannesburg, SA) were wetted in the transport medium and used to sample a $25 \mathrm{~cm}^{2}$ area of all contact surfaces according to standard procedures for environmental swab sampling (Public Health England, 2014). Preharvest samples in the orchard included; hands of pickers and crates. Postharvest samples in the packhouse included, hands of workers, processing line (sortand pack-line), taps (bathroom and wash station) and floors. In the cold room; floors and walls were sampled. All packhouse equipment was recorded as being cleaned daily with water and soap. All samples were transported on ice, stored refrigerated and processed within $24 \mathrm{~h}$ (water) to $48 \mathrm{~h}$ (fruit) and swabs were processed within one week after collection.

\subsection{Hazard characterisation}

Water samples $(100 \mathrm{ml})$ were processed for Colilert- $18^{\circledR}$ (Dehteq, SA) analysis as per manufacturer's instructions and incubated at $37{ }^{\circ} \mathrm{C}$. Results were recorded and the most probable number (MPN) of coliforms and E. coli were determined.

Further to this water samples $(1000 \mathrm{ml})$, fruit sample rinsates and swab samples were analyzed for the presence of $E$. coli 0157:H7, Listeria spp., Salmonella Typhimurium and S. aureus using molecular PCR detection. Water samples $(1000 \mathrm{ml})$ used for molecular detection were filtered through a $0.45 \mu \mathrm{m}$ nitrocellulose filter. Fruit samples were washed in $500 \mathrm{ml}$ quarter strength Ringer's solution (Merck, SA) amended with $0.02 \%$ Tween- 80 in an ultrasonic bath for $5 \mathrm{~min}$ and subsequently filtered through a $0.45 \mu \mathrm{m}$ nitrocellulose filter.

Filters and swabs were analysed by placing each into $9 \mathrm{ml}$ tryptone soy broth, shake incubated $(100 \mathrm{rpm})$ at $37^{\circ} \mathrm{C}$ for $48 \mathrm{~h}$ followed by DNA extraction and PCR with negative control, as outlined by Standing, du Plessis, Duvenage, and Korsten (2013) targeting the UidA gene of E. coli 0157:H7 (F: 5'-GCG AAA ACT GTG GAA TTG GG-3'; R: 5'-TGA TGC TCC ATA ACT TCC TG-3'; 252bp amplicon) (Cebula, Payne, \& Feng, 1995), the listeriolysin O gene of Listeria spp. (F: 5'-AGC TCT TAG CTC CAT GAG TT-3'; R: 5'-ACA TTG TAG CTA AGG CGA CT-3'; 450bp amplicon) (Thomas, King, Burchak, \& Gannon, 1991), the long polar fimbriae D gene for the detection of Salmonella Typhimurium (F: 5'-TTG CCG GTG GTA CTG ATA GG-3'; R: 5'-TTG CCG GTG GTA CTG ATA GG-3'; 787 bp amplicon) as well as Staphylococcus aureus nuclease gene (F: $5^{\prime}$-TTG CAT ATG TAT GGC AAT TGT T-3'; R: 5'-TTT TGC TTG TGC TTC ACT TTT TC-3'; 655 bp amplicon) (Standing et al., 2013). For positive control purposes, PCR reaction mixtures containing DNA extracted from artificially 
Table 1

Weather data summary (South African Weather Services, 2012).

\begin{tabular}{|c|c|c|c|c|c|c|c|c|}
\hline \multirow{2}{*}{$\frac{\text { Season }}{\text { Period }}$} & \multirow{2}{*}{$\frac{1}{\text { At harvest }}$} & \multicolumn{3}{|l|}{2} & \multicolumn{3}{|l|}{3} & \multirow{2}{*}{$\frac{4}{\text { At harvest }}$} \\
\hline & & Last spray & Between last spray and at harvest & At harvest & Last spray & Between last spray and at harvest & At harvest & \\
\hline Date & $04 / 01 / 2007$ & $29 / 09 / 2007$ & & $10 / 10 / 2007$ & $05 / 11 / 2008$ & & $09 / 12 / 2008$ & $04 / 12 / 2009$ \\
\hline Rainfall & $24.4 \mathrm{~mm}$ & $11.7 \mathrm{~mm}$ & $43 \mathrm{~mm}$ & $43 \mathrm{~mm}$ & $5.6 \mathrm{~mm}$ & $89.6 \mathrm{~mm}$ & $8 \mathrm{~mm}$ & $29.8 \mathrm{~mm}$ \\
\hline Day temperature & $32.4{ }^{\circ} \mathrm{C}$ & $23.9^{\circ} \mathrm{C}$ & & $25.9{ }^{\circ} \mathrm{C}$ & $27.5^{\circ} \mathrm{C}$ & & $34.6^{\circ} \mathrm{C}$ & $32{ }^{\circ} \mathrm{C}$ \\
\hline
\end{tabular}

Table 2

Sample collection summary.

\begin{tabular}{|c|c|c|c|c|c|c|}
\hline \multirow{2}{*}{$\begin{array}{l}\text { Time of Season } \\
\text { Spray }\end{array}$} & \multirow{2}{*}{$\begin{array}{l}\text { Type of sample } \\
\text { Water }\end{array}$} & \multirow{2}{*}{$\frac{\text { Number of samples }}{30}$} & \multirow{2}{*}{$\begin{array}{l}\text { Location } \\
\text { Holding Dam } 1(n=10)\end{array}$} & \multicolumn{3}{|c|}{ Season collected } \\
\hline & & & & 2 & 3 & \\
\hline & & & Holding Dam $2(\mathrm{n}=10)$ & 2 & 3 & \\
\hline & & & River $(\mathrm{n}=10)$ & 2 & 3 & \\
\hline \multirow[t]{9}{*}{ Harvest } & & 65 & Holding Dam $1(\mathrm{n}=15)$ & 1 & 2 & 4 \\
\hline & & & Holding Dam $2(\mathrm{n}=15)$ & 1 & 2 & 4 \\
\hline & & & $\operatorname{River}(\mathrm{n}=15)$ & 1 & 2 & 4 \\
\hline & & & Pesticide fill point $(\mathrm{n}=10)$ & 2 & 4 & \\
\hline & & & Washwater $(\mathrm{n}=10)$ & 2 & 4 & \\
\hline & Fruit & 60 & Orchard $(n=40)$ & 1 & 2 & \\
\hline & & & Before Pack $(\mathrm{n}=10)$ & 2 & 4 & \\
\hline & & & After Pack $(\mathrm{n}=10)$ & 2 & 4 & \\
\hline & Contact Surfaces & 273 & Hands $(\mathrm{n}=57)$; Environmental $(\mathrm{n}=216)^{\mathrm{a}}$ & 2 & 4 & \\
\hline
\end{tabular}

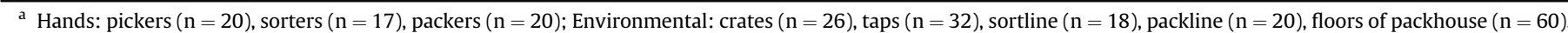
walls and floors coldroom $(n=60)$.

inoculated peaches were used, peaches were artificially inoculated with $10^{2} \mathrm{cfu} /$ fruit of $E$. coli 0157:H7 (ATCC 35150), L. monocytogenes (ATCC 19115), Salmonella Typhimurium (ATCC 14028) and S. aureus (ATCC 12600). PCR amplicons were visualized following gel electrophoresis on a $2 \%(\mathrm{w} / \mathrm{v})$ agarose gel containing $0.1 \%(\mathrm{v} / \mathrm{v})$ Ethidium Bromide.

Statistical analysis was performed on the most probable numbers, using GenStat for Windows Discovery Edition 2 Software (VSN International Ltd., Lawes Agricultural Trust, UK). A one-way analysis of variance (no blocking) was used to determine the significant differences between times of sampling as well as between sampling location. Means were analyzed using Fischer's protected $t$-test least significant difference at a $1 \%$ level of significance.

\subsection{Horticultural safety management system assessment}

Possible risk areas and control activities on the farm were determined using a self-diagnostic tool (Kirezieva et al., 2013). Briefly, the tool was designed to assess the riskiness of a production system's output by taking the system design, operation and specific context in which the system operates into account. The tool assessed the contextual factors affecting the design and operational activities (Kirezieva et al., 2013) and the effectiveness of the core control and assurance activities (Kirezieva et al., 2015). Contextual factors were assigned a rating from 1 (lowest risk) to 3 (highest risk). Control activities and assurance activities were assessed and rated from 1 (lowest performance) to 4 (highest performance). The final system output gave an indication of the level of the system as well as the company's understanding of its own performance (Kirezieva et al., 2013). The information was gathered by conducting an individual interview with the farm managing director.

\subsection{Risk characterisation}

Salmonella Typhimurium was not included in the semiquantitative risk assessment, as no samples tested positive. The Risk Ranger (Ross \& Sumner, 2002), selected as an instrument due to its availability and ease of use, classifies different variables to determine risk. Factors used for the analysis are summarized in Table 3. Risk was characterized as low when the Risk Ranger ranking (RRR) was less than 32, medium when the RRR was between 32 and 48, high when the RRR was between 48 and 60 and very high if the RRR exceeded 60 .

\section{Results}

\subsection{Observations, recommendations and sequence of events}

Each field visit was followed by a report outlining hot spots and areas of improvement for implementation. Livestock were observed to be roaming freely on the farm, with Holding Dam 1 being frequented as a watering hole. Upon sampling in season 2 , during the pesticide spray period it was observed that the banks of Holding Dam 1 were littered with livestock feces. Following that visit $43 \mathrm{~mm}$ of rain fell (Table 1) which resulted in the rise of the dam's water, subsequently the previously exposed and contaminated banks were covered, resulting in the feces mixing with water in the dam. Following season 2's observations and analysis, improvements to the food safety management system and the farm's agricultural practices were implemented. Resulting in the removal of all livestock from the peach production and packaging areas as well as increased cleaning efficiency and properly enforcement of hygiene and sanitation programs, which included food safety follow-up training for workers. Following season 4, the HSMS was assessed and risk characterisation conducted.

\subsection{Hazard characterisation}

Coliform concentrations were higher during the harvest period when compared to the spray period for Holding Dam 1 and 2 for both season 2 and 3, and coliform counts of the River higher in season 2 with no significant difference in season 3 (Fig. 1A) $(p<0.0001)$. Given that the WHO (2006) and Department of Water Affairs and Forestry (1996) recommend that E. coli counts must not exceed 1000 counts per $100 \mathrm{ml}$ for the safe use of grey water for unrestricted drip irrigation, all E. coli counts in water samples were 
Table 3

Information used for the semi-quantitative risk assessment.

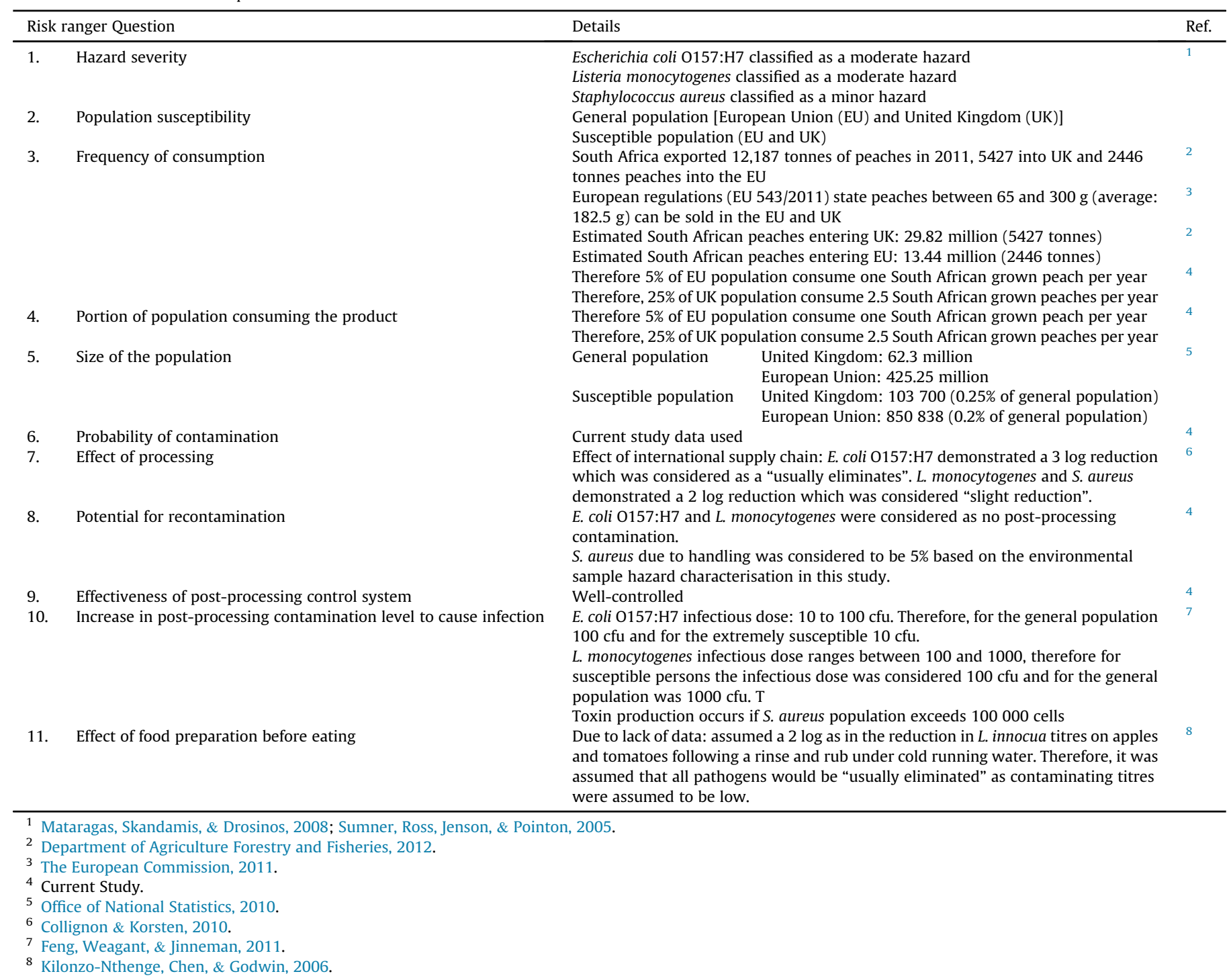

within both guideline limits (Fig. 1B). In contrast to coliform counts, E. coli counts were highest during season 2's spray period for Holding Dam 1 and 2, with E. coli counts for the river highest during season 3's spray period (Fig. 1B).

Samples that tested positive for E. coli 0157:H7, Listeria spp. and S. aureus are outlined in Table 4. Salmonella Typhimurium was not detected from water, fruit or contact surfaces ( $n=428$ samples). No Listeria spp. and S. aureus were detected from the 65 water samples. A total of 25 samples tested positive for E. coli 0157:H7. During season 2 the water contamination rate was $12.5 \%$, with $11.3 \%$ fruit and contact surfaces contamination rate. Listeria spp. were detected three times over the three seasons, with one fruit (season 1), one packer's hand (season 2) and one cold room floor (season 4) sample testing positive. Seven samples tested positive for $S$. aureus with an overall contamination rate of $1.7 \%$. Six of the seven positive S. aureus samples were detected in season 2, mainly from the packhouse $(n=6)$. No isolations were made and no characterisations was therefore done.

\subsection{Horticultural safety management system assessment}

The diagnostic tool assessment (Fig. 2) demonstrated the microbiological risks identified for the production of peaches (Table 5). Contextual factors that led to higher (negative) risk scoring included the subtropical climate and open cultivation as well as the contaminated nature of the source water. Water control and method of irrigation therefore was an important control strategy. Drip irrigation mitigated the microbial contamination risk of the final product, unfortunately water was not regularly tested with no remedial action implemented on the farm. There was generalized cleaning of the facility with no formal design and no scheduled analysis was conducted in order to determine the effectiveness of hygiene implementation, as is required for a more favourable risk assessment, this resulted as a negative risk factor. The tailored handwashing facility with appropriate instructions and cleaning material was rated as being a low to medium risk (score 3). No food safety complaints were recorded and no assessment of possible microbial contamination was conducted, as is required for a more favourable risk ranking. The evaluation of the farms food safety management system was audited by a third party annually, as is required and therefore received a score of 3 . Despite all the favourable attributes implemented the overall score of the food safety output of the HSMS is poor-moderate. 

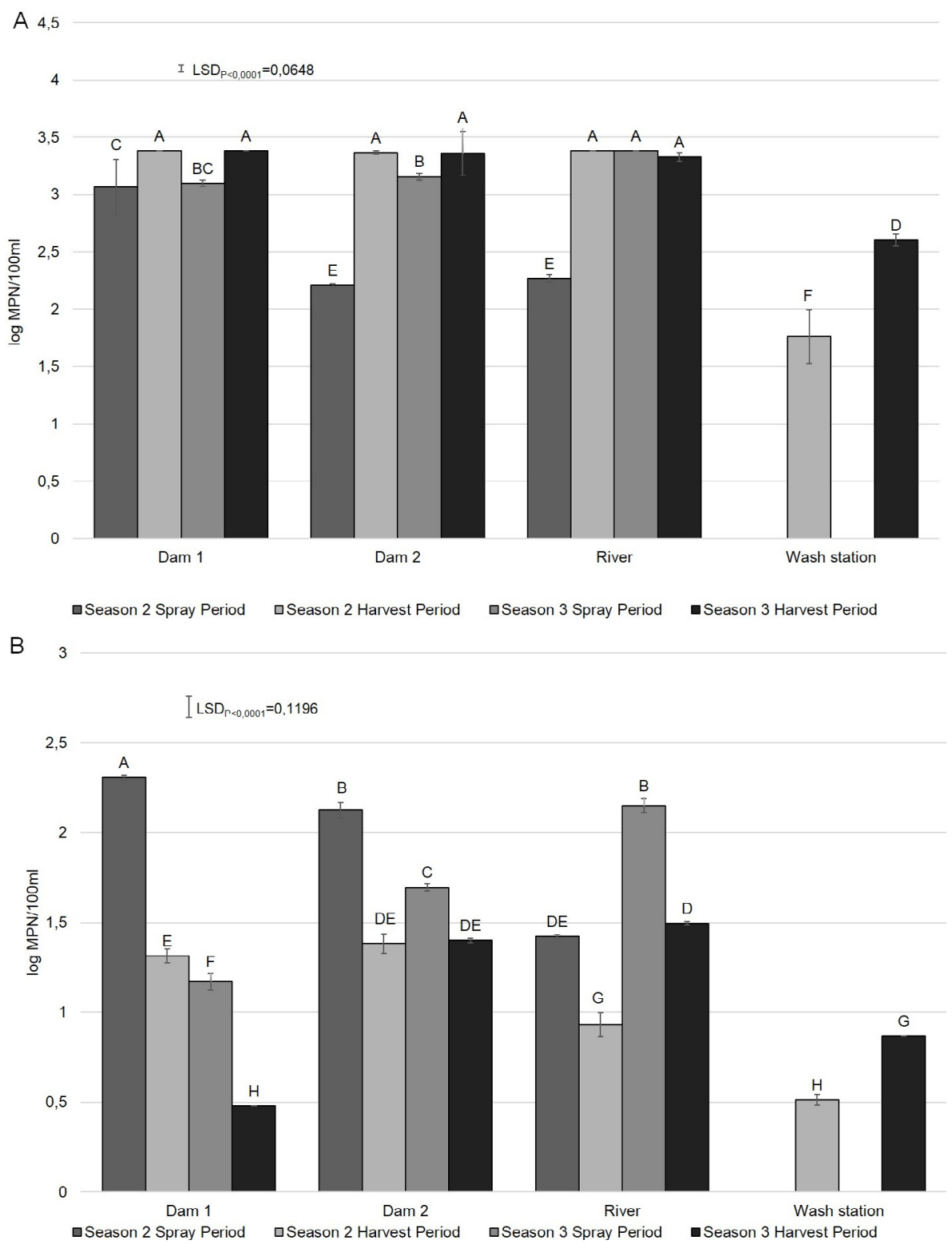

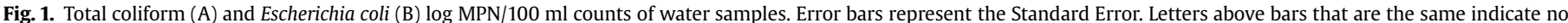
significant difference $(P<0.0001)$. LSD represents the least significant difference.

\subsection{Risk characterisation}

Table 6 presents the risk ratings and estimated potential illnesses following the consumption of peaches in the international market (UK and EU). Only peaches possibly contaminated with L. monocytogenes were demonstrated to pose a medium risk to consumers (general and extremely susceptible) in the UK and EU (Risk ranking for UK: 37 and 39, and for EU: 33 and 35). In the UK, the total predicted illnesses per annum were calculated as 23.40 in the general population and 0.12 in the extremely susceptible population. In the EU, the total predicted illnesses in the general population were calculated as 31.9 and 0.13 in the extremely susceptible population. The calculated risk to consumers eating peaches that were potentially contaminated with E. coli 0157:H7 and $S$. aureus was low. With a total of 0.47 and 0.64 predicted illnesses associated with E. coli 0157:H7-peach combination in the general population in the UK and EU, respectively and 0.002 predicted illnesses in the extremely susceptible population.
Staphylococcus aureus-peach combination resulted in higher predicted illness but the risk of the illnesses was lower and therefore resulted in lower overall risk ranking.

\section{Discussion}

Escherichia coli was detected in all agricultural water sources sampled in this case study. However, none exceeded the guideline values, therefore at the time of the study the water quality of the Lephalala River was found to be compliant (Department of Water Affairs and Forestry, 1996; WHO, 2006). Compliance is necessary for GlobalG.A.P. and to ensure an effective food safety management system. In contrast, other river systems tested in SA reflected higher contamination levels, as a result of surrounding or upstream contamination due to being densely populated with human settlement, mining or industry activities (Chigor, Sibanda, \& Okoh 2013; Du Plessis, Duvenage, \& Korsten, 2015; van Dyk, De Bruin, Du Plessis, \& Korsten, 2016; Gemmell \& Schmidt, 2012, 2013). 
Table 4

Sample result summary of Escherichia coli 0157:H7, Listeria spp and Staphylococcus aureus present in or on water, fruit or contact surfaces.

\begin{tabular}{|c|c|c|c|c|}
\hline \multirow{3}{*}{$\begin{array}{l}\text { Pathogen detected } \\
\text { Escherichia coli } \\
0157\end{array}$} & \multicolumn{2}{|c|}{$\begin{array}{l}\text { Point of contamination per } \\
\text { sample type }\end{array}$} & \multirow{2}{*}{$\begin{array}{l}\text { No. } \\
\text { contaminated }\end{array}$} & \multirow{2}{*}{$\begin{array}{l}\text { Season } \\
2\end{array}$} \\
\hline & Water & Holding dam 1 & & \\
\hline & & River & 2 & 2 \\
\hline & Fruit & Before packing & 1 & 2 \\
\hline & Contact & Pickers crates & 4 & 2 \\
\hline & Surfaces & $\begin{array}{l}\text { Washstation } \\
\text { Taps }\end{array}$ & 1 & 2 \\
\hline & & Sortline & 1 & 2 \\
\hline & & Packers' Hands & 1 & 2 \\
\hline & & Packhouse Floors & 10 & 2 \\
\hline & & Cold Room Walls & 1 & 2 \\
\hline & & $\begin{array}{l}\text { Cold Room } \\
\text { Floors }\end{array}$ & 1 & 4 \\
\hline \multirow[t]{3}{*}{ Listeria spp. } & Fruit & Fruit on trees & 1 & 1 \\
\hline & Contact & Pickers' hands & 1 & 2 \\
\hline & Surfaces & Cold room floors & 1 & 4 \\
\hline \multirow[t]{5}{*}{$\begin{array}{l}\text { Staphylococcus } \\
\quad \text { aureus }\end{array}$} & Fruit & $\begin{array}{l}\text { Fruit in } \\
\text { packhouse }\end{array}$ & 1 & 2 \\
\hline & Contact & Pickers' hands & 3 & 2 \\
\hline & Surfaces & $\begin{array}{l}\text { Washstation } \\
\text { Taps }\end{array}$ & 1 & 2 \\
\hline & & Cold room floors & 1 & 2 \\
\hline & & Packers' hands & 1 & 4 \\
\hline
\end{tabular}

However, this case study did not demonstrate the same trend of polluted agricultural water. Even though this farm was compliant in terms of hazard prevalence (based on the HSMS contextual criteria), the water supply was characterized as high risk, due to its source. Generally, in SA water sourced from a river is considered high risk and therefore additional control is required (Steele \& Odumeru, 2004).

South African rivers have also been shown to pose a risk of transferring bacterial pathogens onto irrigated fresh produce confirming the risky context that the water supply plays in terms of fresh produce safety (Du Plessis et al., 2015; Gemmell \& Schmidt, 2012; Ijabadeniyi, Debusho, Vanderlinde, \& Buys, 2011; Olaniran, Naicker, \& Pillay, 2009). In our study, E. coli 0157:H7 was detected from agricultural water samples. The presence of this pathogen demonstrated a level of risk if using contaminated water. However, the use of drip irrigation mitigated the risk (Markland et al., 2012;
Table 5

Horticultural safety management system assessment of farms.

\begin{tabular}{ll}
\hline $\begin{array}{l}\text { Horticultural Safety Management } \\
\text { Assessment Points }\end{array}$ & Overall Food Safety Output \\
\hline Mean product and process assessment & 2.5 Medium-high risk \\
Mean organisation and chain & 2.5 Medium-high risk \\
\hline Mean control activities design & 2.1 Basic Control \\
Mean control activities operation & 1.7 Basic Control \\
Mean assurance activities & 2.1 Basic Control \\
Mean food safety output & 2.8 Poor-moderate Food Safety \\
& Output \\
\hline
\end{tabular}

van Dyk et al., 2016). A 7.7\% overall E. coli 0157:H7 presence in water samples was recorded. Surface water quality is difficult to control due to possible contamination by livestock and human activity (Kirby, Bartram, \& Carr, 2003; Odumeru et al., 1999).

In SA, informal settlements as well as livestock upstream of river sources have been reported to cause contamination of these water sources as well as municipal pollution (Gemmell \& Schmidt, 2012; Gomba, Chidamba \& Korsten, 2016; Müller, Ehlers, \& Grabow, 2001; Odjadjare \& Okoh, 2010). Increased contamination with E. coli 0157:H7 can be explained by the observations of livestock frequenting the holding dam. Cattle in Africa have the highest percentage of $E$. coli 0157:H7 prevalence (Islam et al., 2014). In South Africa, the prevalence of E. coli 0157:H7 in the North West Province has been recorded between $5.4 \%$ and $20 \%$ in cattle (Ateba, Mbewe, \& Bezuidenhout, 2006). Coliforms and E. coli O157:H7 were found to increase which could be linked to higher water levels after rain which resulted in flooding of the banks of the dam. We surmise that contamination of the holding dam was caused by the presence of livestock which led to increased presence of coliforms and $E$. coli 0157:H7 in the source water. The lack of E. coli 0157:H7 detection in the subsequent season following removal of the livestock further supports this assumption. In further support of this, Hagedorn et al. (1999) and Tanaro et al. (2014) correlated the presence of bacterial pathogens with the presence of livestock. However, the generic $E$. coli counts did not increase, it is a well-known fact that $E$. coli 0157:H7 is glucuronidase negative and therefore its increase was not detected using the Coli-lert. Future isolation, characterisation and source tracking studies as conducted by Du Plessis et al. (2015)

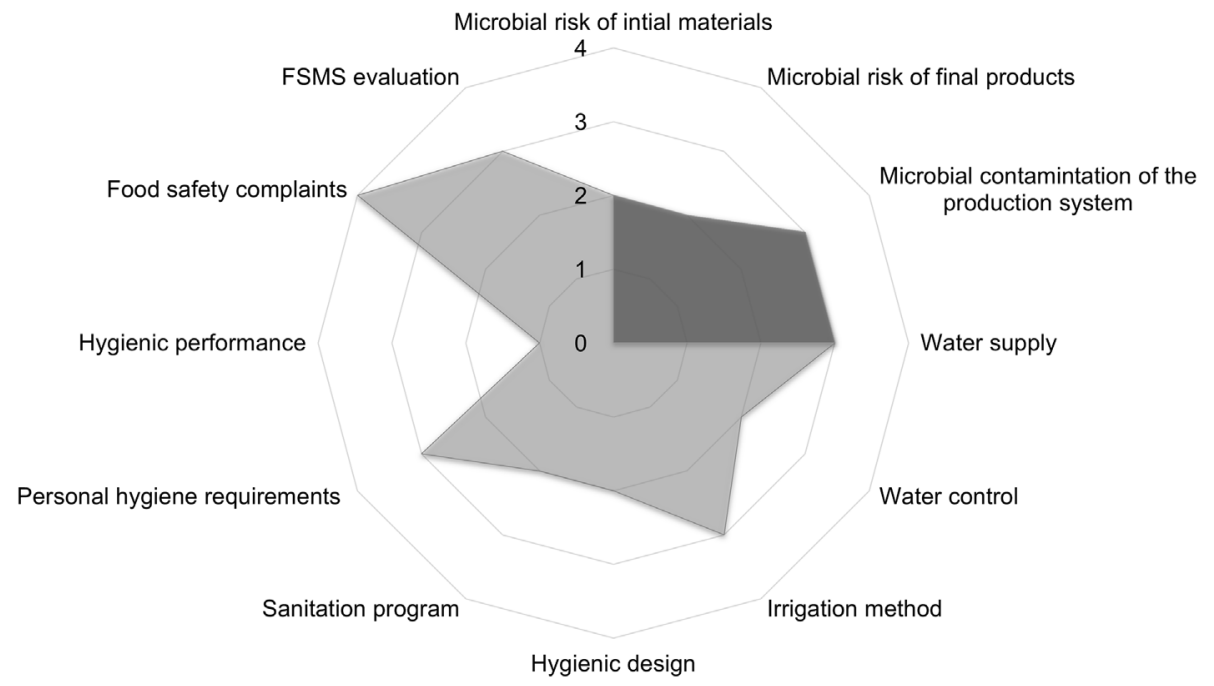

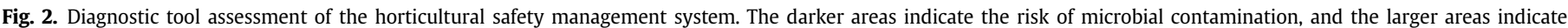

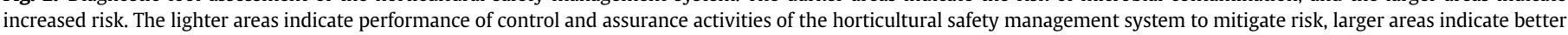
performance. 
Table 6

Risk ranking summary of peaches following export to the United Kingdom and the European Union for the low and high susceptible consumers.

\begin{tabular}{|c|c|c|c|c|c|c|}
\hline \multirow[t]{2}{*}{ Hazard } & \multirow{2}{*}{$\begin{array}{l}\text { Export } \\
\text { Destination }\end{array}$} & \multirow{2}{*}{$\begin{array}{l}\text { Susceptibility of } \\
\text { Consumer }\end{array}$} & \multicolumn{4}{|l|}{ RISK, controlled post-processing } \\
\hline & & & $\begin{array}{l}\text { Probability of illness per day per consumer of } \\
\text { interest (Pinf } \mathrm{x} \text { Pexp) }\end{array}$ & $\begin{array}{l}\text { Total predicted illnesses/annum in } \\
\text { population of interest }\end{array}$ & $\begin{array}{l}\text { Risk Ranking } \\
\text { Score }\end{array}$ & Ranking \\
\hline $\begin{array}{c}\text { Escherichia coli } \\
\text { 0157:H7 }\end{array}$ & $\begin{array}{l}\text { United } \\
\text { Kingdom }\end{array}$ & General & $8,22 \mathrm{E}-11$ & 4,67E-01 & 28 & Low \\
\hline $\begin{array}{l}\text { Escherichia coli } \\
\text { 0157:H7 }\end{array}$ & $\begin{array}{l}\text { United } \\
\text { Kingdom }\end{array}$ & Extremely & $1,64 \mathrm{E}-07$ & $2,34 \mathrm{E}-03$ & 29 & Low \\
\hline $\begin{array}{c}\text { Escherichia coli } \\
\text { 0157:H7 }\end{array}$ & $\begin{array}{l}\text { European } \\
\text { Union }\end{array}$ & General & $8,22 \mathrm{E}-11$ & $6,38 \mathrm{E}-01$ & 24 & Low \\
\hline $\begin{array}{c}\text { Escherichia coli } \\
\text { O157:H7 }\end{array}$ & $\begin{array}{l}\text { European } \\
\text { Union }\end{array}$ & Extremely & $1,64 \mathrm{E}-07$ & $2,55 \mathrm{E}-03$ & 25 & Low \\
\hline $\begin{array}{l}\text { Listeria } \\
\quad \text { monocytogenes }\end{array}$ & $\begin{array}{l}\text { United } \\
\text { Kingdom }\end{array}$ & General & 4,11E-09 & $2,34 \mathrm{E}+01$ & 37 & Medium \\
\hline $\begin{array}{l}\text { Listeria } \\
\quad \text { monocytogenes }\end{array}$ & $\begin{array}{l}\text { United } \\
\text { Kingdom }\end{array}$ & Extremely & $8,22 \mathrm{E}-06$ & 1,17E-01 & 39 & Medium \\
\hline $\begin{array}{l}\text { Listeria } \\
\quad \text { monocytogenes }\end{array}$ & $\begin{array}{l}\text { European } \\
\text { Union }\end{array}$ & General & 4,11E-09 & $3,19 \mathrm{E}+01$ & 33 & Medium \\
\hline $\begin{array}{l}\text { Listeria } \\
\quad \text { monocytogenes }\end{array}$ & $\begin{array}{l}\text { European } \\
\text { Union }\end{array}$ & Extremely & $8,22 \mathrm{E}-06$ & $1,28 \mathrm{E}-01$ & 35 & Medium \\
\hline $\begin{array}{l}\text { Staphylococcus } \\
\quad \text { aureus }\end{array}$ & $\begin{array}{l}\text { United } \\
\text { Kingdom }\end{array}$ & General & $4,11 \mathrm{E}-10$ & $2,34 \mathrm{E}+00$ & 20 & Low \\
\hline $\begin{array}{l}\text { Staphylococcus } \\
\quad \text { aureus }\end{array}$ & $\begin{array}{l}\text { United } \\
\text { Kingdom }\end{array}$ & Extremely & $8,22 \mathrm{E}-08$ & 1,17E-03 & 16 & Low \\
\hline $\begin{array}{l}\text { Staphylococcus } \\
\text { aureus }\end{array}$ & $\begin{array}{l}\text { European } \\
\text { Union }\end{array}$ & General & $4,11 \mathrm{E}-10$ & $3,19 \mathrm{E}+00$ & 16 & Low \\
\hline $\begin{array}{l}\text { Staphylococcus } \\
\quad \text { aureus }\end{array}$ & $\begin{array}{l}\text { European } \\
\text { Union }\end{array}$ & Extremely & $8,22 \mathrm{E}-08$ & $1,28 \mathrm{E}-03$ & 12 & Low \\
\hline
\end{tabular}

Risk $<32$ is considered low, risk between 32 and 48 is considered medium, risk between 48 and 60 is considered high and risk $>60$ is considered very high.

and Jongman and Korsten (2016) should be done to confirm this.

The self-assessment tool revealed that the farm met basic hygiene and sanitation requirements. During season 2, an $11.5 \%$ prevalence of $E$. coli $0157: \mathrm{H7}$ in environmental samples was determined which corresponded to the findings of Cooley et al. (2007) from environmental samples (water, soil and dust) for two vegetable farms. During this study, E. coli 0157:H7 was detected on peach crates, on the sortline and on a packer's hands during season 2 , all of which represent potential sources of contamination. All contact surfaces on this farm were washed using purified water. However, at the time of sampling the water used for cleaning purposes tested negative for E. coli 0157:H7. The packhouse and cold room floors as well as cold room walls were also contaminated with E. coli 0157:H7. Eighty percent of E. coli 0157:H7 $(n=10)$ detected from samples collected from packhouse floors were found to be at the entrance to the packhouse. The likelihood that E. coli 0157:H7 was carried into the packhouse on the soles of workers' shoes entering the facility was considered as a possible explanation requiring further investigation. A previous study conducted found that after a new pair of shoes were worn for two weeks, coliforms and $E$. coli were detected on the outside of the shoes (Cleaning Industry Research Institute Staff, 2011). The same study also demonstrated the transfer of bacteria from the source of origin to the participant's households. An important consideration is that only one peach sample was found to be contaminated with E. coli 0157:H7. In addition, in subsequent years following feedback to the farm management and better implementation of facility sanitation there was a definite decrease in E. coli $0157: \mathrm{H} 7$ prevalence on environmental samples with none detected on fruit and water samples. In addition, Collignon and Korsten (2010) demonstrated that E. coli O157:H7 was unable to survive the peach export supply chain at levels that were able to cause disease. Therefore, taking the frequency of contamination, the effect of processing, the effect of the supply chain and the population consuming the potentially contaminated product into account the level of risk to the consumer was found to be low, even when the HSMS selfassessment demonstrated that the hygiene and sanitation were basic. Future research should focus on preventative measures, behavioral correction and disinfectant efficacy, to avoid the contamination with E. coli $\mathrm{O} 157: \mathrm{H} 7$ as it can indirectly lead to fruit contamination.

In this study hygiene practices and a moderate sanitation program implemented were rated as good. Despite these perceived good and moderate practices implemented, hand and contact surface contamination with S. aureus was found. Staphylococcus aureus was not detected on fruit that were harvested from trees or prior to packing, therefore the contamination of fruit is most probably taking place through human handling after harvest. Feng, Li, Lv, Xu, and Wu (2014) reported detection of S. aureus, in their case study, $14 \mathrm{~S}$. aureus isolates were confirmed positive from fresh fruit and environmental samples, suggesting that the postharvest contamination needed to be addressed, which was in agreement with our findings. Contamination with S. aureus found in these studies, was attributed too poor personal and facility hygiene. The significant detection of $S$. aureus from fruit and farm workers' hands and the wash station tap during season 2 and the fact that contamination decreased following the improvement of facility sanitation and enforcement of proper hygiene practices is evidence that the personal and facility hygiene did not comply with minimal food safety management standards in season 2. Primary producers should therefore focus their food safety management systems on training staff in the correct hygiene and sanitation practices and procedures required to assure compliance in personal hygiene and environmental sanitation. A high contamination rate of $S$. aureus resulted in a low risk to the UK and EU consumer due to the fact that the pathogen is not considered a major pathogen as the illness that can result is not severe and an infectious dose of $10^{5} \mathrm{cfu}$ is required in order to produce toxins (Food and Drug Administration, 2012).

In the 428 samples analysed only three tested positive for Listeria spp. one from a picker's hand, one from cold room floor 
sample and one from a tree fruit sample. Listeria spp. and L. monocytogenes are often found as an environmental organism present due to soil or silage contamination. If peaches become contaminated with high concentrations of $L$. monocytogenes the organism has the potential to survive at cold chain conditions at levels that could exceed the minimum infectious dose (Collignon \& Korsten, 2010). Due to these factors the calculated risk to the consumer in the UK and EU was determined to be medium with a predicated illness per annum of 23.40 and 31.9. Future research should determine the presence and source of the $L$. monocytogenes contamination as well as isolation and characterisation of isolates to allow source tracking.

In this study, Salmonella Typhimurium was not detected in water, fruit or contact surfaces sampled. In 2012, Salmonella spp. was reportedly the most important bacterial pathogen in terms of number of foodborne disease outbreaks (CDC, 2012). Similarly, a number of studies have not detected Salmonella spp. from samples tested (Pagadala et al., 2015 with $\mathrm{n}=422$; Feng et al., 2014 with $\mathrm{n}=407$; Feng et al., 2014 with $\mathrm{n}=890$ ). In contrast, Gomba et al. (2016) found antimicrobial resistant Salmonella spp. isolates from fruit, water and environmental samples within a fresh fruit production system in SA as did van Dyk et al. (2016) who found two environmental samples positive. Gomba et al. (2016) concluded that Salmonella spp. contamination resulted due to SA municipal pollution, however this was not the case in this study. In Africa, Salmonella Typhimurium and Salmonella Enteritidis are the two most commonly reported serovars associated with human isolates (Galanis et al., 2006). In South Africa, Salmonella Typhimuirum was also most commonly isolated from animal origin with 917 incidents when compared to only 232 incidents of Salmonella Enteritidis, with $65 \%$ from poultry and $20 \%$ from cattle (Kidanemariam, Engelbrecht, \& Picard, 2010). However, in the USA over the past nine years Salmonella Enteritidis has not been associated with a multistate outbreak associated with fruit, while Salmonella Typhimurium has been associated with fruit, twice. Future studies should focus on determining the prevalence and characterisation of Salmonella spp. in the peach supply chain systems in order to conclude that Salmonella spp. are not a risk factor associated with peach consumption.

The employed detection methodology could lead to an underestimation of foodborne pathogens present in the peach supply chain due to the use of a non-selective enrichment step. Future research should focus on improving this rapid screening test to include a two-phase detection system based on International Standard Operating Procedures to allow for the isolation and characterisation of foodborne pathogens possibly detected. However, this study used a unique approach of combining microbiological sampling and self-diagnostic- and risk-assessment tools. The integration of these knowledge platforms and tools provide a more realistic assessment of actual and perceived risks. It is interesting to note that this farm was certified to GlobalG.A.P. prior to the commencement of this study and this study found it to be initially non-compliant in terms of microbiological specifications. This brings to mind the actual impact of certification versus selfimprovement. The farmer feedback strategy further realized a more compliant production system with areas of self-improvement being effectively implemented.

\section{Conclusion}

In conclusion, Salmonella Typhimurium was not molecularly detected on any of the water, fruit or contact surface samples $(\mathrm{n}=428)$ analyzed in this case study. On single occasions $E$. coli 0157:H7, Listeria spp. and S. aureus were detected on fruit as well as on contact surfaces and food handler's hands. It is well known that a food product can become contaminated when in contact with a contaminated surface which can lead to cross-contamination of the final product. Following proper implementation and enforcement of the food safety management system, contamination within the packhouse decreased. In spite of these improvements the assessment of the HSMS reflected poor-moderate food safety output. Despite molecular detection of E. coli 0157:H7, Listeria spp. and $S$. aureus on this farm, the overall risk to the end consumer was found to be low for E. coli 0157:H7 and S. aureus and medium L. monocytogenes using the Risk Ranger. This is mostly due to the fact that these pathogens were detected in a single season at low frequency and that the product goes through an extended period of export under controlled cold temperatures, reducing the likelihood of survival of any potential pathogens at low frequency. Future studies should focus on isolation of foodborne pathogens to allow characterisation, and ultimately source tracking and linking pathogens from various contamination areas.

\section{Acknowledgements}

This research was made possible by the funding and support of the Deciduous Fruit Producers' Trust (now Hortgro, SA) (Grant: UPFS1). The financial assistance of the National Research Foundation (NRF) towards this research is hereby acknowledged. Opinions expressed and conclusions arrived at, are those of the author and are not necessarily to be attributed to the NRF. Dr S. Duvenage would like to acknowledge the Department of Science and Technology-NRF Centre of Excellence in Food Security (Project 140701) for financial assistance. The authors would like to acknowledge Ms K. de Reuck, Mr F.J. Duvenage and Mr P. Fourie for laboratory assistance and Ms C. Joubert for logistical support.

\section{References}

Ateba, C., Mbewe, M., \& Bezuidenhout, C. (2006). Prevalence of Escherichia coli 0157 strains in cattle, pigs and humans in North West Province, South Africa. South African Journal of Science, 72(4), 3074-3078.

Beuchat, L. R. (2002). Ecological factors influencing survival and growth of human pathogens on raw fruits and vegetables. Microbes and Infection, 4(4), 413-423.

Cebula, T. A. Payne, W. L. \& Feng P. (1995). Simultaneous identification of strains of Escherichia coli serotype 0157:H7 and their Shiga-like toxin type by mismatch amplification mutation assay-multiplex PCR. Journal of Clinical Microbiology, 33(1), 248-250.

Centers for Disease Control and Prevention. (2012). Surveillance for foodborne disease outbreaks, United States, 2012, Annual report. Atlanta, Georgia: US Department of Health and Human Services, CDC. Retrieved from http://www.cdc.gov/ foodsafety/pdfs/foodborne-disease-outbreaks-annual-report-2012-508c. pdf\#page $=12$

Centers for Disease Control and Prevention. (2015). Multistate outbreak of listeriosis linked to commercially produced, prepackaged caramel apples made from bidart bros. Apples (final update). Retrieved February 17, 2015, from http://www.cdc. gov/listeria/outbreaks/caramel-apples-12-14/index.html.

Chigor, V. N., Sibanda, T., \& Okoh, A. I. (2013). Studies on the bacteriological qualities of the Buffalo River and three source water dams along its course in the Eastern Cape Province of South Africa. Environmental Science and Pollution Research, 20(6), 4125-4136.

Cleaning Industry Research Institute Staff. (2011). Study reveals high bacteria levels on footwear. Retrieved March 20, 2015, from http://www.ciriscience.org/a_96Study_Reveals_High_Bacteria_Levels_on_Footwear.

Collignon, S., \& Korsten, L. (2010). Attachment and colonization by Escherichia coli 0157:H7, Listeria monocytogenes, Salmonella enterica subsp. enterica serovar Typhimurium, and Staphylococcus aureus on stone fruit surfaces and survival through a simulated commercial export chain. Journal of Food Protection, 73(7), 1247-1256.

Cooley, M., Carychao, D., Crawford-Miksza, L., Jay, M. T., Myers, C., Rose, C., et al. (2007). Incidence and tracking of Escherichia coli 0157:H7 in a major produce production region in California. PloS One, 2(11), e1159.

Department of Agriculture, Forestry and Fisheries. (2012). A profile of the South African peach market value chain (pp. 1-69). Retrieved November 25, 2014, from http://www.nda.agric.za/docs/AMCP/Peach2012.pdf.

Department of Water Affairs and Forestry. (1996). South African water quality guidelines. In Agricultural Use: Irrigation (2nd ed., Vol. 4). Pretoria, South Africa: The Government Printer.

Du Plessis, E. M., Duvenage, F. J., \& Korsten, L. (2015). Determining the potential link 
between irrigation water quality and the microbiological quality of onions by phenotypic and genotypic characterization of Escherichia coli isolates. Journal of Food Protection, 78(4), 643-651.

European Food Safety Authority (EFSA). (2011). Shiga toxin-producing E. coli (STEC) O104:H4 2011 outbreaks in Europe. EFSA Journal, 9(10), 2390-2412.

Feng, Y., Li, G., Lv, X., Xu, Y., \& Wu, Q. (2014). Prevalence, distribution, and diversity of Escherichia coli, Staphylococcus aureus, and Salmonella in kiwifruit orchards and processing plants. Foodborne Pathogens and Disease, 11(10), 782-790.

Feng, P., Weagant, S., \& Jinneman, K. (2011). Chatper 4A: Diarrheagenic Escherichia coli. In Bacteriological analytical manual. Center for Food Safety and Applied Nutrition. Retrieved from http://www.fda.gov/Food/FoodScienceResearch/ LaboratoryMethods/ucm070080.htm.

Food Science Australia. (2000). Packaged minimally-processed fresh-cut vegetables. In Food safety and hygiene-a bulletin for the australian food industry. Food Science Australia. Retrieved October 20, 2009, from www.dfst.csiro.au/fshbull/fshbull21. htm.

Food and Drug Administration. (Center for Food Safety and Applied Nutrition, 2012). Bad bug book: Handbook of foodborne pathogenic microorganisms and natural toxins.

Galanis, E., Lo Fo Wong, D., Patrick, M., Binsztein, N., Cieslik, A., Chalermchaikit, T., et al., World Health Organization Global Salm-Surv. (2006). Web-based surveillance and global Salmonella distribution, 2000-2002. Emerging Infectious Diseases, 12(3), 381-388.

Gemmell, M., \& Schmidt, S. (2012). Microbiological assessment of river water used for the irrigation of fresh produce in a sub-urban community in Sobantu, South Africa. Food Research International, 47(2), 300-305.

Gemmell, M., \& Schmidt, S. (2013). Is the microbiological quality of the Msunduzi River (KwaZulu-Natal, South Africa) suitable for domestic, recreational, and agricultural purposes? Environmental Science and Pollution Research, 20(9), 6551-6562.

Gomba, A., Chidamba, L., \& Korsten, L. (2016). Antimicrobial resistance profiles of Salmonella spp. from agricultural environments in fruit production systems. Foodborne Pathogens and Disease, 13(9), 495-501.

Gruszynski, K., Pao, S., Kim, C., Toney, D., Wright, K., Ross, P., et al. (2014). Evaluating wildlife as a potential source of Salmonella serotype Newport (JJPX01. 0061) contamination for tomatoes on the Eastern Shore of Virginia. Zoonoses and Public Health, 61(3), 202-207.

Hagedorn, C., Robinson, S. S. L., Filtz, J. R., Grubbs, S. M., Angier, T. A., \& Reneau, R. B. (1999). Determining sources of fecal pollution in a rural Virginia watershed with antibiotic resistance patterns in fecal streptococci. Applied and Environmental Microbiology, 65(12), 5522-5531.

Ijabadeniyi, O., Debusho, L., Vanderlinde, M., \& Buys, E. (2011). Irrigation water as a potential preharvest source of bacterial contamination of vegetables. Journal of Food Safety, 31(4), 452-461.

Islam, M. Z., Musekiwa, A., Islam, K., Ahmed, S., Chowdhury, S., Ahad, A., et al. (2014). Regional variation in the prevalence of E. coli 0157 in cattle: A metaanalysis and meta-regression. PLoS ONE, 9(4). http://dx.doi.org/10.1371/ journal.pone.0093299.

Jackson, B., Salter, M., Tarr, C., Conrad, A., Harvey, E., Steinbock, L., et al. (2015). Listeriosis associated with stone fruit-United States, 2014. MMWR Morbidity and Mortality Weekly Report, 64(10), 282-283.

Jongman, M., \& Korsten, L. (2016). Genetic diversity and antibiotic resistance of Escherichia coli isolates from different leafy green production systems. Journal of Food Protection, 79(11), 1846-1853.

Kidanemariam, A., Engelbrecht, M., \& Picard, J. (2010). Retrospective study on the incidence of Salmonella isolations in animals in South Africa, 1996 to 2006. Journal of the South African Veterinary Association, 81(1), 37-44.

Kilonzo, C., Li, X., Vivas, E., Jay-Russell, M., Fernandez, K., \& Atwill, E. (2013). Fecal shedding of zoonotic food-borne pathogens by wild rodents in a major agricultural region of the central California coast. Applied and Environmental Microbiology, 79(20), 6337-6344.

Kilonzo-Nthenge, A., Chen, F.-C., \& Godwin, S. L. (2006). Efficacy of home washing methods in controlling surface microbial contamination on fresh produce. Journal of Food Protection, 69(2), 330-334.

Kirby, R., Bartram, J., \& Carr, R. (2003). Water in food production and processing: Quantity and quality concerns. Food Control, 14(5), 283-299.

Kirezieva, K., Luning, P., Jacxsens, L., \& Uyttendaele, M. (2015). Status of food safety management activities in fresh produce companies in the European Union and beyond. Acta Horticulturae, 1103, 167-174.

Kirezieva, K., Nanyunja, J., Jacxsens, L., van der Vorst, J., Uyttendaele, M., \& Luning, P. (2013). Context factors affecting design and operation of food safety management systems in the fresh produce chain. Trends in Food Science and Technology, $32,108-127$.

Markland, S., Shortlidge, K., Cook, L., LeStrange, K., Sharma, M., \& Kniel, K. (2012).
A comparison of $E$. coli persistence on basil plants and soil using drip and overhead irrigation. In 2012 annual meeting of the international association for food protection, $\mathrm{P} 3-123$.

Mataragas, M., Skandamis, P. N., \& Drosinos, E. H. (2008). Risk profiles of pork and poultry meat and risk ratings of various pathogen/product combinations. International Journal of Food Microbiology, 126, 1-12.

Müller, E., Ehlers, M., \& Grabow, W. (2001). The occurrence of E. coli 0157: H7 in South African water sources intended for direct and indirect human consumption. Water Research, 35(13), 3085-3088.

Odjadjare, E., \& Okoh, A. (2010). Prevalence and distribution of Listeria pathogens in the final effluents of a rural wastewater treatment facility in the Eastern Cape Province of South Africa. World Journal of Microbiology and Biotechnology, 26(2), 297-307.

Odumeru, J. J. A., Steele, M., Fruhner, L., Jiang, J., Mann, E., Mcnab, W. B., et al. (1999). Evaluation of accuracy and repeatability of identification of food-borne pathogens by automated bacterial identification systems. Journal of Clinical Microbiology, 37(4), 944-949.

Office of National Statistics. (2010). Statistical bulletin: Annual mid-year population estimates, 2010. United Kingdom: Office for National Statistics; Newport, United Kingdom.

Olaniran, A., Naicker, K., \& Pillay, B. (2009). Antibiotic resistance profiles of Escherichia coli isolates from river sources in Durban, South Africa. World Journal of Microbiology and Biotechnology, 25(10), 1743-1749.

Pagadala, S., Marine, S., Micallef, S., Wang, F., Pahl, D., Melendez, M., et al. (2015) Assessment of region, farming system, irrigation source and sampling time as food safety risk factors for tomatoes. International Journal of Food Microbiology, 196, 98-108.

Public Health England. (2014). Detection and enumeration of bacteria in swabs and other environmental samples. Microbiology services food water and environmenta microbiology procedures standard method. London: Public Health England. Retrieved from https://www.gov.uk/government/uploads/system/uploads/ attachment_data/file/329432/Detection_and_enumeration_of_bacteria_in_ swabs_and_other_environmental_samples.pdf.

Ross, T., \& Sumner, J. (2002). A simple, spreadsheet-based, food safety risk assessment tool. International Journal of Food Microbiology, 77(1), 39-53.

South African Weather Services. (2012). Weather data, South African Weather Services, Pretoria, South Africa.

Standing, T.-A., du Plessis, E., Duvenage, S., \& Korsten, L. (2013). Internalisation potential of Escherichia coli 0157:H7, Listeria monocytogenes, Salmonella enterica subsp. enterica serovar Typhimurium and Staphylococcus aureus in lettuce seedlings and mature plants. Journal of Water and Health, 11(2), 210.

Steele, M., \& Odumeru, J. (2004). Irrigation water as source of foodborne pathogens on fruit and vegetables. Journal of Food Protection, 67(12), 2839-2849.

Sumner, J., Ross, T., Jenson, I., \& Pointon, A. (2005). A risk microbiological profile of the Australian red meat industry: Risk ratings of hazard-product pairings. International Journal of Food Microbiology, 105(2), 221-232.

Tanaro, J., Piaggio, M., Galli, L., Gasparovic, A., Procura, F., Molina, D., et al. (2014). Prevalence of Escherichia coli 0157: H7 in surface water near cattle feedlots. Foodborne Pathogens and Disease, 11(12), 960-965.

Tauxe, R., Kruse, H., Hedberg, C., Potter, M., Madden, J., \& Wachsmuth, K. (1997). Microbial hazards and emerging issues associated with produce: A preliminary report to the national advisory committee on microbiologic criteria for foods. Journal of Food Protection, 60(11), 1400-1408.

The European Commission. (2011). Commission Implementing Regulation (EU) No 543/2011 of 7 June 2011. Official Journal of the European Union. Retrieved October 23, 2012 from http://eur-lex.europa.eu/LexUriServ/LexUriServ.do? uri=OJ:L:2011:157:0001:0163:EN:PDF.

Thomas, E. J., King, R. K., Burchak, J., \& Gannon, V. P. (1991). Sensitive and specific detection of Listeria monocytogenes in milk and ground beef with the polymerase chain reaction. Applied and Environmental Microbiology, 57(9), 2576-2580.

van Dyk, B., De Bruin, W., Du Plessis, E. M., \& Korsten, L. (2016). Microbiological food safety status of commercially produced tomatoes from production to marketing. Journal of Food Protection, 79(3), 392-406.

Warriner, K., Huber, A., Namvar, A., Fan, W., \& Dunfield, K. (2009). Chapter 4 recent advances in the microbial safety of fresh fruits and vegetables. Advances in food and nutrition research (1st ed.) (1st ed., Vol. 57)). Elsevier Inc.

World Health Organisation. (2011). EHEC outbreak: Update 13, 10/06/2011. Retrieved October 6, 2011, from http://www.euro.who.int/en/what-we-do/health-topics/ emergencies/international-health-regulations/news/news/2011/06/ehecoutbreak-update-13.

World Health Organization. (2006). Guidelines for the safe use of wastewater, excrete and Greywater: Policy and regulatory aspects (Vol. 1). World Health Organisation. 